Petri Jylhä

Matti Suominen

Jussi-Pekka Lyytinen

Arbitrage capital and

currency carry trade returns 
Petri Jylhä - Matti Suominen - Jussi-Pekka Lyytinen

\author{
ARBITRAGE CAPITAL \\ AND \\ CURRENCY CARRY TRADE \\ RETURNS
}

A Financial Markets and Services Research Paper

For more finance related research at HSE, see www.hse.fi/fms/

November

2008 
HELSINGIN KAUPPAKORKEAKOULU

HELSINKI SCHOOL OF ECONOMICS

PL 1210

FI-00101 HELSINKI

FINLAND

(C) Petri Jylhä, Matti Suominen, Jussi-Pekka Lyytinen

Helsinki School of Economics

ISSN 1235-5674

(Electronic working paper)

ISBN 978-952-488-294-1

Helsinki School of Economics -

HSE Print 2008 


\title{
Arbitrage Capital and Currency Carry Trade Returns
}

\author{
Petri Jylhä, Matti Suominen and Jussi-Pekka Lyytinen ${ }^{1}$
}

Current version: November 11, 2008

\begin{abstract}
We develop a model based on risk averse investors and limited arbitrage capital to explain the rationale for the so called carry trades: that is, trades where "the purchase of riskier, higher-yielding assets is funded by selling lower-yielding currencies" (Financial Times, January 28, 2008). In our model, due to partially segmented markets and differences in inflation risk and money supply, the returns to carry trades are positive, but decrease in the amount of arbitrage capital. In the empirical part of the paper, using 32 years of exchange rate data, we document several new results related to carry trades and provide empirical support for the model's predictions. We empirically document that 1) carry trade returns explain a significant part of hedge fund index returns, providing strong evidence that carry trades are indeed used by arbitrageurs, 2) the positive returns to carry trades have been decreasing over time in parallel with an increase in arbitrage capital, 3) the real interest rates are higher in countries with higher inflation risk and higher per capita money supply, but higher arbitrageurs' equity capital and a better funding liquidity for them decrease the cross country differences in real interest rates, 4) flow of new arbitrage capital leads to an appreciation (depreciation) of the carry long (short) currencies.
\end{abstract}

At the time of the paper, there is an ongoing large outflow of arbitrage capital from hedge funds, and this has been associated with a large appreciation of Japanese yen, US dollar and Swiss franc and a large depreciation of euro, Canadian dollar and British pound, in relation to most other currencies. These currency movements are consistent with our results, as at the time of the paper yen, US dollar and Swiss franc are carry trade short currencies and euro, Canadian dollar and British pound are carry trade long currencies.

Key words: Carry Trades, Arbitrage Capital, Risk Arbitrage

\footnotetext{
${ }^{1}$ All authors are from the Helsinki School of Economics. E-mail of the corresponding author is matti.suominen@hse.fi. We thank Rui Albuquerque, Harald Hau, Markku Lanne, Massimo Massa, Stefan Nagel, Vasant Naik, Dimitri Vayanos, Adrien Verdelhan and the seminar participants at the Adam Smith Asset Pricing Conference, Bank of Finland, and Helsinki School of Economics for helpful comments. Jylhä thanks the Finnish Foundation for Advancement of Securities Markets and the Okobank Group Research Foundation for financial support.
} 


\section{Introduction}

In this paper, we develop a simple model to explain the rationale for the so called currency carry trades: that is, trades where "the purchase of riskier, higher-yielding assets is funded by selling lower-yielding currencies" (Financial Times, January 28, 2008). The model reflects the intuition given by Grossman in his AFA Presidential Address in 1995 that the interest rate differentials across countries do not reflect merely the expected depreciation or appreciation of currencies, but also real rewards to the world for bearing risks related to investments in the respective currencies. Besides studying a stylized theoretical model that reflects this intuition, we present several new empirical results regarding the profitability of the carry trades and the effect of carry trade activity on interest rates and exchange rates.

Carry trading is today far from a marginal activity, but rather an important strategy for at least a large part of the hedge fund industry. Due to a massive increase in the amount of funds managed by these institutions, carry trades have in recent years had a price impact on both currency and interest rates across the world. One consequence of this, we argue, is that the returns to carry trades have been decreasing over time. According to our results, the carry traders transfer funds from low real interest rate countries to high real interest rate countries. Although this activity is presumably good for the global allocation of resources, it has some alarming consequences. First, it affects the local monetary authorities control over their monetary policy and second it may subject the economies to large swings in their currency and interest rates, when the level of the arbitrage activity changes. For these reasons, among others, it is imperative that we continue to develop models to better understand the carry trading phenomenon and to empirically study its effects on currency and interest rates. Our paper is an attempt to do so. ${ }^{2}$

\footnotetext{
${ }^{2}$ On October $26^{\text {th }} 2008$, the financial ministers and central bank presidents of the Group of Seven major industrial countries issued a joint statement in which they expressed their concern about the recent volatility of the yen, a currency
} 
The carry trading phenomenon is closely related to a large literature on international asset pricing that focuses on the uncovered interest rate parity (UIP). Over the last few decades, several papers have studied a related observed anomaly, called forward premium puzzle, which is essentially the observation that high interest rate countries' currencies do not significantly depreciate, but in fact according to some studies appreciate, in relation to low interest rate countries' currencies, see e.g., Bilson (1981), Froot and Thaler (1990), Bekaert (1996), Engel (1996) or Bansal and Dahlquist (2000). This finding implies that on average carry trades are profitable. Although it is typically agreed that there must be some time varying currency specific risk premiums in the foreign exchange markets, that explains the returns to carry trades, there is no general agreement on the origins of these risk premiums. Recent studies on the profitability of carry trades include Burnside, Eichenbaum, Kleshchelski and Rebelo (2006) and Lustig, Roussanov and Verdelhan (2008).

Our model has two countries, whose risk-averse consumers can only invest in their own country's securities markets, due to prohibitively high transaction costs. In addition, living on an island in between, there are a limited number of risk-averse arbitrageurs, who can buy and sell short fixedincome securities in all markets. Similar assumption of limited arbitrage capital (or limited number of risk-averse unrestricted investors) is present e.g., in Gromb and Vayanos (2002) and Brunnermeier and Pedersen (2007). ${ }^{3}$ In our model, due to random shocks, the inflation risk varies across the two countries. With segmented markets and inflation risk premiums in nominal fixed income assets, as previously discussed e.g., in Korajczyk (1985), in the absence of arbitrageurs and other things equal, the equilibrium expected real interest rate offered by the nominal fixed income

\footnotetext{
that in our sample has most commonly been used as a funding currency in carry trades. During one month the yen had appreciated by more than $30 \%$ against the euro.

${ }^{3}$ Earlier the idea of market segmentation and institutional constraints on the availability of arbitrage capital was present e.g., in Keynes (1923) and Einzig (1961). Some market segmentation has prevailed in the foreign exchange market as the barriers to cross border investments were historically large until the 1990s especially for individual investors. In many countries there are ongoing limitations to foreign currency investments (see e.g., IMF report on exchange arrangemets, restrictions and controls, 2007).
} 
securities is higher in the country with the higher inflation risk. In the presence of arbitrageurs, who in equilibrium engage in carry trades, this differential in expected real interest rates (differential in inflation risk premiums) across countries is reduced. ${ }^{4,5}$

On the theoretical side, we extend the existing literature (reviewed below) by developing a stylized model that is consistent with the carry trade phenomenon, and which makes some new predictions on the sources of carry trade returns and the effect of arbitrage capital on equilibrium interest rates, currency rates and carry trade returns. In our model, the real interest rates depend on inflation risk, per capita money supply and the amount of arbitrage capital. Our model predicts that the returns to carry trades are positive, but decrease when arbitrage capital increases. Furthermore, it predicts that when arbitrage capital increases, interest rates in high (low) interest rate countries decline (rise), and their currencies appreciate (depreciate).

On the empirical side, using 32 years of exchange rate data, we present several new results and provide empirical support for the model's predictions. Our key findings are that 1) carry trade returns explain a significant part of hedge fund index returns, providing strong evidence that carry trades are indeed used by arbitrageurs, 2) the positive returns to carry trades have been decreasing over time in parallel with an increase in arbitrage capital, 3) the real interest rates are higher in countries with higher inflation risk and higher per capita money supply, but higher arbitrageurs' equity capital and a better funding liquidity for them decrease the differences in real interest rates across countries, 4) flow of new arbitrage capital leads to an appreciation (depreciation) of the carry

\footnotetext{
${ }^{4}$ Other papers that have studied the effect of inflation uncertainty on forward premiums include Grauer, Litzenberger and Stehle (1976), Kouri (1977), Fama and Farber (1979) and more recently Bansal and Dahlquist (2000). The idea of inflation risk premium in interest rates is present e.g., in Fama (1976), Buraschi and Jiltsov (2005) and Ang, Bekaert and Wei (2008).

${ }^{5}$ The carry trade investments are not risk free and thus not arbitrage in the traditional sense. This type of investments are, however, commonly referred to as "risk arbitrage."
} 
long (short) currencies. These results, which are consistent with our model, show clearly that arbitrageurs' carry trading activity has had a price impact in the global foreign exchange markets.

One recent paper close in spirit to ours is Brunnermeier, Nagel and Pedersen (2008). Their paper shows that carry trades are subject to currency crash risk, i.e., the exchange rate movements of carry trade portfolios are negatively skewed. They argue that this skewness in foreign exchange rates follows from temporary changes in the availability of funding liquidity to arbitrageurs. When the funding liquidity is temporarily reduced, this results in a rapid unwinding of the traders' positions and thus leads to abrupt changes in the exchange rates, which go against the carry traders. This risk, they argue, is a major factor affecting traders' willingness to enter into these "risk arbitrage" positions and arbitrage away the positive returns to carry trades. Their risk based explanation to carry trade returns complements ours and our finding of different levels of per capita inflation risks in high and low interest rate countries.

In fact, also our results do support the importance of funding liquidity. Empirically we find that the availability of funding capital, as measured by the level of TED (Treasury to Eurodollar) spread, has had an effect on interest rates, and that changes in TED spread have affected carry trade returns. TED spread is a measure that e.g., Brunnermeier, Nagel and Pedersen (2008) use to measure funding liquidity. While the role of funding liquidity is undisputed, we argue and our results clearly show that it has become more important in recent years as the amount of arbitrage capital, i.e., the amount of assets under management in hedge funds, has become large. Furthermore, our results show that funding liquidity is only one of the factors affecting currency carry trade returns and in addition at least the level of arbitrage capital and the flow of such capital are important determinants of carry trade returns. 
The other existing literature on the subject can be organized into four categories. First, Roll and Yan (2000) question the validity of the statistical inference procedures underlying the early literature regarding the forward premium puzzle. Moreover, Lyons (2001) and Wagner (2008) argue that certain statistically significant deviations from UIP are not economically significant if they do not result in speculative profits with high enough Sharpe ratios.

Second, there is a large literature that studies if the forward premium puzzle can be explained with a time-varying risk premium component in the forward exchange rate. In addition to those mentioned above, see e.g., Fama (1984), Cumby (1988), Backus, Gregory and Telmer (1993), Bekaert, Hodrick and Marshall (1997), Hollifield and Uppal (1997), Mark and Wu (1998), Backus, Foresi and Telmer (2001), Bansal and Shaliastovich (2006), Alvarez, Atkenson and Kehoe (2007), Lustig and Verdelhan (2007), Verdelhan (2007) and Farhi and Gabaix (2008). These papers typically look at a two country multi-period investment and consumption problem, and study if the puzzle can be explained by imperfections in the goods markets, transaction costs, non-traditional utility functions or the time series properties of the spot exchange rates. To match with the data they tend to require high levels of risk aversion or high intertemporal elasticity of substitution. Our model is also an attempt to explain the forward premium puzzle with currency specific risk premiums. In contrast to the previous, however, we argue that the large past abnormal returns to carry trades were due to market frictions, i.e., to limited arbitrage capital. As the frictions have been reduced and arbitrage capital has grown, the returns to carry trades have decreased. Our empirical findings are consistent with this idea.

Third category of papers addressing the forward premium puzzle are those based on market microstructure frictions explored e.g., by Burnside, Eichenbaum and Rebelo (2007b). In their model a risk neutral market maker faces an adverse selection problem since she does not know whether 
she receives orders from informed or uninformed traders. The probability of informed buy and sell orders depends on whether the currency is expected to appreciate or depreciate. To deal with this, the market maker sets the forward ask and bid rates asymmetrically, which in their model results in the forward premium bias. Somewhat related to our model and empirical findings, Plantin and Shin (2008) show that under carry costs and financing externalities carry trade profitability can become self-fulfilling: traders buying into a high-yielding currency put upward pressure on the price of the currency and the failure of UIP is thus a consequence of carry trades.

Finally, the fourth category of related papers relies on imperfections in information processing. Albuquerque (2007) models agents that do not perfectly observe shocks driving the monetary policy. Optimal updating of conditional expectations using Kalman filter leads to fixed time effects and conditional heteroscedasticity in the UIP regression. He also shows empirically that this specification significantly weakens the forward premium puzzle. In Gourinchas and Tornell (2004) agents learn about the nature of the interest rate shocks (transitory or persistent), but there is an irrational misperception about the second moments of interest rate forecasts that never disappears, resulting in the forward premium puzzle. In Bacchetta and van Wincoop (2006) the forward premium puzzle is explained through infrequent updating of information and management of portfolios. Finally, using a model where overconfident agents overreact to their private signals, Han, Hirshleifer and Wang (2007) provide a behavioral explanation for the forward premium puzzle.

Our paper is also connected to two strands of hedge fund literature. First, our results are related to papers studying the relationship between hedge fund flows and returns, see e.g. Goetzmann, Ingersoll and Ross (2003), Getmansky (2004), Baquero and Verbeek (2005), Agarwal, Daniel and Naik (2008), Ding, Getmansky, Liang and Wermers (2008), Fung, Hsieh, Naik and Ramadorai 
(2008), and Wang and Zheng (2008). Second, our results also complement those of Fung and Hsieh (2000) and Ding, Getmansky, Liang and Wermers (2007) who study the impact of hedge funds on the financial markets as a whole.

The rest of the paper is organized as follows: In section 1 we develop the model and in section 2 we show the theoretical results. Sections 3-6 contain the empirical part of the paper. In section 3 we present the data. In section 4, we document the carry trade returns and the effect of arbitrage capital on those returns. In section 5, we study how arbitrage capital has affected interest rates, while section 6 studies the effect of arbitrage capital flows on exchange rates. Section 7 concludes the paper.

\section{The Model}

There are two countries, $A$ and $B$, and two periods of time $t=1$ and $t=2$. The consumers (also referred to as "investors") in these two countries consume apples and are endowed with plenty of time $t=1$ apples. They have prohibitively high transaction costs from investing in the other country than their own and thus invest only in their own country of residence. ${ }^{6}$ The amount of such investors in both countries is normalized to one.

There are two storage technologies in both countries $i \in\{A, B\}: 1)$ a risk free storage technology in unlimited supply, whose return is normalized to zero (the apples do not rot); 2) a risky storage technology, also referred to as the risky asset, whose per capita supply in country $i$ equals $M_{i}>0$. Our interpretation is that the risky storage technology in country $i$ (risky asset) corresponds to short term nominal fixed income securities issued by the government $i$ at $t=1$ at a "per unit" price of $P_{i}$

\footnotetext{
${ }^{6}$ This assumption of segmented markets is effectively similar to that in the preferred habitat models, see e.g., Vayanos and Vila (2007).
} 
measured in time $t=1$ apples. One unit or "one share" of such risky asset gives a random real payoff equal to

$$
V_{i}=1+\varepsilon_{i}
$$

apples in period $t=2$. Here $\varepsilon_{i}, i \in\{A, B\}$, are two independent normally distributed random variables reflecting the inflation risk in such nominal securities in any given country, with mean zero and standard deviation $\sigma_{\mathrm{i}}$. Note that we do not explicitly model the nominal payoff itself, but rather directly the real payoff from the nominal securities. We assume that $\sigma_{\mathrm{i}}, i \in\{A, B\}$, are drawn from the same continuous distribution, implying that $M_{i} \sigma_{i}^{2} \neq M_{j} \sigma_{j}^{2}$ with probability one. We assume that the time $t=1$ the wealth of the investors in both countries $i, \underline{W}_{i 1}$, exceeds their $t=1$ equilibrium investment in the risky asset.

In addition to the countries $A$ and $B$, there exists an island in between the two countries. On the island there lives $K$ arbitrageurs, who have low transaction costs and can sell short the risky asset in one country, while investing the proceeds in the risky asset of the other country. These islanders have no time $t=1$ apples, but have plenty of time $t=2$ apples (and can thus cover the possible losses from their risk arbitrage activities). An additional assumption is that the islanders cannot borrow using the riskless securities, i.e., the baskets of commodities cannot be sold short.

Timing:

$t=1$ : In the beginning of the period $M_{i}$ and $\sigma_{i}$ are determined for both countries $i \in\{A, B\}$. After this, investors and arbitrageurs make their investment decisions.

$t=2$ : The final payoff to the risky assets is determined as $V_{i}=1+\varepsilon_{i}$ apples.

All investors are risk averse and have a constant absolute risk aversion: 


$$
U=-\exp \left(-a W_{2}\right)
$$

for their period $t=2$ wealth, $W_{2}$. Here $a$ is the parameter of risk aversion. Equilibrium exists when investors' actions maximize their utility, taking the other players' strategies as given, and markets clear.

Our interpretation is thus that the risky asset corresponds to money, i.e., a short term nominal fixed income security. The risk in this security is the inflation risk, which does not exist in a risk free investment made directly into a basket of goods. We interpret the ratio of the time $t=1$ prices of the risky assets in countries $A$ and $B, P_{A} / P_{B}$, as the time $t=1$ currency exchange rate. This is the rate at time $\mathrm{t}=1$ at which the two countries nominal securities can be exchanged in the market.

\section{Equilibrium}

\subsection{Investments into risky assets in the absence of arbitrageurs}

In both countries the investors choose their level of investment in the risky asset by selecting the number of shares purchased, $\lambda_{i}$. The investors maximize: ${ }^{7}$

$$
\begin{aligned}
& \max _{\lambda i} E-\exp \left(-a \underline{W}_{i 1}-a \lambda_{i}\left(1+\varepsilon_{i}-P_{i}\right)\right) \\
& =-\exp \left(-a\left(\underline{W}_{i 1}+\lambda_{i}\left(1-P_{i}\right)-1 / 2 a \lambda_{i}{ }^{2} \sigma_{i}{ }^{2}\right)\right) .
\end{aligned}
$$

Using the first order condition to (3), $\lambda_{i}=\left(1-P_{i}\right) /\left(a \sigma_{i}^{2}\right)$, and the market clearing condition, $\lambda_{i}=M_{i}$, we obtain:

\footnotetext{
${ }^{7}$ Our setting matches that commonly used to study investments in shares of risky assets under uncertainty and CARA utility.
} 


$$
P_{i}=1-a M_{i} \sigma_{i}^{2}
$$

In the absence of arbitrageurs, i.e., when $K=0$, the expected gross return from investing in the risky asset, i.e., the equilibrium gross interest rate is thus:

$$
R_{i} \equiv 1+r_{i} \equiv 1 / P_{i}=1 /\left(1-a M_{i} \sigma_{i}^{2}\right)
$$

Equation (5) implies that in the absence of arbitrageurs, the equilibrium interest rate is higher in the country with the higher per capita inflation risk, $M_{i} \sigma_{i}{ }^{2}$. If we denote by $H$ the country with the higher per capita inflation risk, $i \in \operatorname{argmax}\left\{M_{A} \sigma_{A}{ }^{2}, M_{B} \sigma_{B}{ }^{2}\right\}$, and by $L$ the country with the lower per capita inflation risk, then equation (5) implies that $r_{H}>r_{L}$. The higher interest rate in country $H$ is necessary to attract a sufficient amount of investments into the risky asset in order to clear the market, despite the higher risk. Due to the difference in the expected real interest rates, there would exist an opportunity for an arbitrageur to borrow from country $L$ and invest the proceeds in country $H$ and earn a positive expected return. We now turn to this possibility.

\subsection{The role of arbitrageurs}

Now, assume $K>0$, so there are some arbitrageurs present in the market. We assume that the arbitrageurs are endowed with a time $t=2$ wealth of $\underline{W}_{2}$. As we show below, the presence of arbitrageurs in the market reduces the differential in the expected returns between the risky assets in countries $A$ and $B$, but, when $K<\infty$, it does not eliminate the return differential. 
The arbitrageurs maximize their utility by selecting the number of "shares" of the risky asset purchased in country $H, \lambda_{H}^{a}$, financed by selling short $-\lambda_{L}^{a}$ "shares" of the risky asset in country $L$. That is, they maximize: ${ }^{8}$

$$
\begin{aligned}
& \max _{\lambda_{H}^{a}, \lambda_{L}^{a}} E-\exp \left(-a \underline{W_{2}}-a\left(\lambda_{H}^{a}\left(1+\varepsilon_{H}-P_{H}\right)+\lambda_{L}^{a}\left(1+\varepsilon_{L}-P_{L}\right)\right)\right) \\
& \text { subject to }-\lambda_{H}^{a} P_{H} / P_{L}=\lambda_{L}^{a} .
\end{aligned}
$$

This is equivalent to:

$$
\max _{\lambda_{H}^{a}}-\exp \left(-a \underline{W_{2}}-a\left(\lambda_{H}^{a}-\lambda_{H}^{a} P_{H} / P_{L}-1 / 2 a \lambda_{H}^{a}{ }^{2} \sigma_{H}{ }^{2}-1 / 2 a\left(\lambda_{H}^{a} P_{H} / P_{L}\right)^{2} \sigma_{L}^{2}\right)\right)
$$

The first order condition to the maximization problem gives:

$$
\lambda_{H}^{a}=\frac{1-P_{H} / P_{L}}{a \sigma_{H}^{2}+\left(P_{H} / P_{L}\right)^{2} a \sigma_{L}^{2}}
$$

and using (7),

$$
\lambda_{L}^{a}=-\lambda_{H}^{a} P_{H} / P_{L}
$$

Now, from (9) and (10) we see that the arbitrageurs do in equilibrium invest a positive amount in the strategy that we conjectured, i.e., $\lambda_{H}^{a}>0$ and $\lambda_{L}^{a}<0$, as long as:

$$
1-P_{H} / P_{L}>0
$$

\footnotetext{
${ }^{8}$ Note that we do not restrict $\lambda_{H}^{a}$ to be positive and $\lambda_{L}^{a}$ to be negative.
} 


$$
\begin{aligned}
& \Leftrightarrow \\
& r_{H}-r_{L}>0,
\end{aligned}
$$

that is, as long as there is a positive "carry". In the case when there were no arbitrageurs, we showed that the interest rate in country $H$ was higher than that in country $L$. In the presence of $K$ arbitrageurs the same result holds, as we show below, and thus the left hand side of (12) remains strictly positive. We also show below, however, that when $K$ increases, the left hand side of (11) and thus the returns to carry trades gradually approach zero.

Given that there are $K$ arbitrageurs, using the market clearing conditions, $\lambda_{i}+K \lambda_{L}^{a}=M_{i}$, we obtain:

$$
\begin{aligned}
& P_{H}=1-\left(M_{H}-K \lambda_{H}^{a}\right) a \sigma_{H}^{2}, \\
& P_{L}=1-\left(M_{L}-K \lambda_{L}^{a}\right) a \sigma_{L}^{2} .
\end{aligned}
$$

Now, using (9), (10), (13) and (14) we obtain:

$$
\frac{P_{H}}{P_{L}}=\frac{1+r_{L}}{1+r_{H}}=\frac{\left(1+K-M_{H} a \sigma_{H}^{2}\right)}{\left(1+K-M_{L} a \sigma_{L}^{2}\right)} .
$$

Equation (15), which is proved in the Appendix, shows that as $K$ increases, the interest rates in the two countries eventually converge to the same level and the currency rate $P_{H} / P_{L}$ approaches monotonically one from below. We summarize these findings in the following propositions: 
Proposition 1: In equilibrium, the arbitrageurs engage in carry trades (borrow from the country with the lower interest rate and invest the proceeds in the country with the higher interest rate). The expected returns from carry trades are positive.

Proposition 2: When $K$, the number of arbitrageurs, increases, the ratio of the gross interest rates, $\left(1+r_{H}\right) /\left(1+r_{L}\right)$, decreases monotonically. In the limit, when $K \rightarrow \infty$, the expected returns to carry trades approach zero.

Proposition 3: An increase in $K$, the number of arbitrageurs, leads to an increase in the exchange rate $P_{H} / P_{L}$.

Proposition 3 thus predicts that the flow of new arbitrage capital (new arbitrageurs) leads to appreciation (depreciation) of the "carry trade" long (short) currencies. Finally, an additional result is that:

Proposition 4: When $\sigma_{H} \rightarrow 0$ or $a \rightarrow 0$ the returns to carry trades approach zero.

The proof of Proposition 1 was outlined in the text and the proofs of Propositions 2, 3 and 4 come directly from equation (15) and are omitted. The result in Proposition 4 is consistent with the finding in Lustig, Roussanov and Verdelhan (2008) that an increase in the VIX volatility index leads to an increase in the expected future returns to carry trades. Finally, when the parameter of risk aversion approaches zero, this also leads to the disappearance of the expected returns from carry trades. 
Next, let us look at what is the effect of carry trading on existing carry trading positions. Define "old carry trade" position as a carry trade position prevailing already in the beginning of time $\mathrm{t}=1$. Although no economic agent in our model has such positions, nothing prevents us from studying how such positions would be affected by the carry trading activity. ${ }^{9}$ A carry trade position is defined as a zero investment position, evaluated at $K=K_{0}$, such that $\lambda_{H}>0$ and $\lambda_{L}<0$.

Proposition 5: Increase in $K$, from $K_{0}$ to $K_{0}+\Delta$, when $\Delta$ is small enough, implies positive contemporaneous $(t=1)$ returns to existing carry trade positions.

Proof follows directly from Proposition 3. This result, which is in line with Plantin and Shin (2008), shows that new carry traders create a positive externality on old carry traders.

In our model, differences in per capita inflation risks lead to capital outflow from the country with the lower per capita inflation risk into the country with the higher level of risk, due to the arbitrageurs' carry trades. One historical example where a real shock affected the capital needs in a country and thus the real interest rates was described in Grossman (1995). He discusses how the high financing needs in Germany after the unification led to a high market interest rate for the German mark, in order to attract sufficient capital into the country.

\section{Empirical Part}

\section{The Data}

To test the predictions of our model empirically, we use a data set that is obtained from Datastream and consists of month-end observations of interbank spot and 1-month forward exchange rates

\footnotetext{
${ }^{9}$ Alternatively, one could include some old carry traders and carry trade positions into our analysis and define the supply of assets $\mathrm{M}_{\mathrm{i}}$ as the money supply net of such positions.
} 
against British pound as well as 1-month interest rates for Belgian franc, British pound, Canadian dollar, euro, French franc, German mark, Italian lira, Japanese yen, Netherlands guilder, Swiss franc, and U.S. dollar. The data covers a 393 month period from January 1976 to September 2008. All currencies are not available in the data set throughout this period, but enter as data becomes available. Data for Japanese yen begins in June 1978 and for euro in January 1999, and data for euro legacy currencies (Belgian franc, French franc, German mark, Italian lira, and Netherlands guilder) ends in December 1998. Altogether, we have 3985 currency-month observations. Although this is not a complete set of currencies, we cannot think of any systematic bias arising from the fact that not all currencies at all times have been included in the data set. Our dataset contains the currencies used e.g., in Burnside, Eichenbaum, Kleshchelski and Rebelo (2006).

Testing the implications of the theoretical model calls for proxies for inflation risk, per capita supply of the fixed income asset, the amount of arbitrage capital and funding liquidity. To find a proxy for the time varying inflation risk, we estimate the following autoregressive model, that also allows for heteroskedasticity, for the rate of inflation, $d_{t}$ :

$$
\begin{aligned}
& d_{t}=\beta_{0}+\sum_{j=1}^{12} \beta_{j} d_{t-j}+e_{t}, \quad e_{t} \sim N\left(0, h_{t}^{2}\right) \\
& h_{t}^{2}=\gamma_{0}+\gamma_{1} h_{t-1}^{2}+\gamma_{2} e_{t-1}^{2} .
\end{aligned}
$$

The model is estimated individually for each country using OECD data on monthly inflation dating back to January 1965 for other countries and January 1990 for euro area. We use the mean equation for $d_{t}$ to produce inflation forecasts and the time varying variance term, $h_{t}^{2}$, as our proxy for the inflation risk. The approach is similar to those used by e.g., Grier and Perry (1998) and Hwang (2001). 
Our proxy for per capita supply of the fixed income asset is M2 money supply divided by stock market capitalization. As the stock market capitalization reflects the size of the financial markets in a given country, we believe this ratio captures well a given country's citizens' ability to bear the inflation risk related to its monetary assets, thus capturing the intuition of the model. The data on M2 is from IMF, National Bank of Belgium, Bank of England, and Mitchell (1992). Most of this data is on a monthly frequency. In the few cases when monthly observations are not available, we calculate monthly estimates assuming that the growth of M2 between annual observations has been constant. Stock market capitalizations are from Datastream and World Federation of Exchanges. ${ }^{10}$

Our proxy for the amount of arbitrage capital is the hedge fund industry's total assets under management (AUM) divided by the total M2 money supply of our sample countries. We divide the AUM figures by M2 to get a proxy of the proportion of arbitrage capital from the total capital invested in the short term fixed income securities markets.

It is in fact quite difficult to obtain good monthly estimates for the hedge fund industry's AUM dating back in time. There is only scattered data on this. First, Hedge Fund Research, Inc. (HFR) provides annual estimates of the hedge fund industry's total AUM from 1990 onwards. Second, we find some evidence on the size of the markets for the earlier period from Hennessee Group LLC, but it is only for the years 1974 and 1987. In addition to these, we have the Lipper TASS database, which provides monthly observations on individual funds and covers the entire data period, and covers a large (currently $80 \%$ ) but varying proportion of the total hedge fund industry.

We deal with this problem in the following way. To form a monthly series of the hedge fund AUM, we start with the annual estimates of the total hedge fund AUM by HFR and the two earlier

\footnotetext{
${ }^{10}$ We use M2 instead of e.g., M3 as this is available for all countries during our sample period.
} 
estimates by Hennessee. Next, we calculate asset weighted averages of returns and new asset flows to all the funds included in the Lipper TASS database for each month. As the year-to-year asset growth of the Lipper TASS funds does not match the growth in hedge fund industry indicated by the estimates provided by HFR and Hennessee, due to the changing coverage in Lipper TASS, we make the assumption that each year the difference between the two growth figures accumulates steadily over the year. Hence, our estimated hedge fund AUM growth is the asset weighted average growth in the AUM of the hedge funds reporting to Lipper TASS database plus one twelfth of the difference in the current year's asset growth estimates obtained from HFR or Hennessee and the Lipper TASS database. In this way we get a monthly estimate of the hedge fund AUM whose endof-year figure matches the estimates of HFR and Hennessee and whose monthly growth pattern resembles as closely as possible that of the population of funds reporting to Lipper TASS database. ${ }^{11}$ Figure 1 shows the historical development of the arbitrage capital proxy, i.e. hedge fund AUM divided by the total M2 money supply. The total hedge fund AUM grows from just over $0.1 \%$ of the total M2 in 1976 to over $6 \%$ in 2007 and sharply falls down to less than 5\% during the third quarter of 2008. The first sharp decline happens in the fall of 1998, during the LTCM crisis.

\section{[Insert Figure 1 here]}

Our estimate of hedge fund industry's asset flow is based on all funds in the Lipper TASS database and our AUM estimates. We calculate an estimate of percentage asset flow to each fund for each month when reported asset and return figures are available, take an asset weighted average of these percentage flows, and multiply this by our estimate of the total hedge fund industry AUM to obtain an estimate of the flow in dollar terms. As for the hedge fund AUM, we divide the dollar flow by the total M2 money supply of our sample currencies to get a proxy of the AUM flow that is

\footnotetext{
${ }^{11}$ Some discussion on the difficulties of finding good proxies to measure carry trade activity can be found in Galati, Heath and McGuire (2007).
} 
proportional to the size of the short term fixed income markets. We are able to calculate the monthly flow estimates starting from March 1977.

Finally, as a proxy for funding liquidity we use the TED (Treasury over Eurodollar) spread, defined as the difference between 3 month interbank interest rate on US dollar and the risk free 3 month Treasury bill interest rate. TED spread is used as a proxy for funding liquidity also in Brunnermeier, Nagel and Pedersen (2008).

\section{Arbitrage capital and carry trade returns}

In order to analyze currency carry trades, we trace the returns to a very simple carry trade strategy. At the end of each month, we rank the currencies according to their forward premiums. We sell pounds forward in the currencies that rank in the top third and buy pound forward in the bottom third currencies. At the end of the next month, the forwards are settled, a new ranking is composed and new forward contacts are entered into. This approach differs somewhat from that used by Burnside, Eichenbaum, Kleshchelski and Rebelo (2006) and Burnside, Eichenbaum and Rebelo (2007a) who sell pound forward in all the currencies that have a positive forward premium and buy pound forward in all the currencies that have a negative forward premium. Our approach of leaving out middle ranking currencies matches that commonly used in the asset pricing literature and is similar to that used for currencies e.g., by Lustig and Verdelhan (2007) and Lustig, Roussanov and Verdelhan (2008). Similarly, when analyzing the effects of carry trading activity in the subsequent sections of this paper, we assume that all carry traders follow this particular (but seemingly popular) carry trade strategy. We calculate the carry trade returns using the mid rates of the bid and the ask quotes. 
The first conclusion of the theoretical model is that the carry trades are profitable. Table 1 presents the descriptive statistics for monthly gross returns on our carry trade strategy and Figure 2 shows the cumulative return, in pounds, to a constant 100 pound size investment in the long-short carry trade portfolio.

[Insert Table 1 and Figure 2 here]

The mean monthly return to carry trades is $0.49 \%$, which corresponds to a $5.88 \%$ annual return and is statistically very significant. The standard deviation of the monthly returns is $2.03 \%$ resulting in a monthly Sharpe ratio of 0.244 (0.854 annualized). ${ }^{12}$ To allow for some comparison, over the same time period, S\&P 500 had an average monthly return of $0.72 \%$, monthly standard deviation of $4.20 \%$ and monthly Sharpe ratio of 0.123 . These results are in line with those by Burnside, Eichenbaum, Kleshchelski and Rebelo (2006), allowing for the fact that their method of constructing portfolios slightly differs from ours. The profitability of carry trades, although decreasing profitability, is evident from Figure $2 .^{13}$

The average level of interest rates is $3.48 \%$ in the short portfolio and $9.96 \%$ in the long portfolio, resulting in an interest return of $6.48 \%$ on annual basis or $0.54 \%$ on monthly basis. On average, exchange rate movements have only reduced the returns by $0.05 \%$ per month. If uncovered interest parity held, the average currency return should be close to the negative of the interest return, but it

\footnotetext{
${ }^{12}$ Since the carry trade is a zero investment strategy, Sharpe ratio is simply the average of returns divided by the standard deviation of returns.

${ }^{13}$ Trading forwards and settling them monthly induces significant transaction costs, although bid-ask spreads are small for our sample of currencies. Over the sample period the average monthly trading costs are $0.31 \%$ of the portfolio value. After transaction costs, the average monthly net return from carry trades is thus $0.18 \%$, which corresponds to an annual net return of $2.20 \%$. Note that these transaction costs are only available for professional investors corresponding to arbitrageurs in our model. Individual investors, presumably, have much higher transaction costs. On the other hand, professional investors may be able to trade at better prices than by merely buying at the end-of-month ask and selling at the end-of-month bid.
} 
only is $8 \%$ of that value. Table 2 shows the total number of months each currency is in each of the portfolios.

\section{[Insert Table 2 here]}

The simulated positions of the carry traders roughly correspond to our intuition that carry traders borrow from stable inflation and capital rich countries, where M2 per investor and inflation risk is small (like Switzerland, Germany and Japan), and invest the proceeds to less wealthy or less inflation stable economies (such as Italy, France and UK).

Second prediction of our model is that arbitrageurs "trade carry." As also in Lyytinen (2007), Table 3 presents the correlation between carry trade portfolio and equity, bond and hedge fund indices. We use the Standard \& Poor's 500 as equity index, Lehman US Aggregate as bond index and Credit Suisse/Tremont Hedge Fund index family as hedge fund indices.

[Insert Table 3 here]

Carry trade returns have a low correlation with both equity and bond returns. The correlation with hedge fund returns, however, is positive and statistically significant, which indicates that arbitrageurs do, indeed, engage in currency carry trades. Of the hedge fund sub-indices, carry trade returns are most highly correlated with fixed income arbitrage and global macro strategies. ${ }^{14}$

To further study these funds' exposure to carry trades we regress the hedge fund index returns on a number of previously used risk factors, as well as our currency carry trade return, and test if the

\footnotetext{
${ }^{14}$ Some additional evidence related to hedge funds' exposure to individual currency carry trade pairs was presented in McGuire and Upper (2007).
} 
currency carry trade factor is significant. More precisely, we augment the seven hedge fund risk factor model of Fung and Hsieh (2004) by adding the return of our currency carry trade strategy as the eighth factor. ${ }^{15}$ We regress the returns of the broad hedge fund index as well as global macro and fixed income arbitrage indices on the seven and eight factors and report the results in Table 4.

\section{[Insert Table 4 here]}

As Table 4 shows, all three hedge fund indices presented have a statistically significant exposure to the currency carry trade factor. The currency carry trade factor appears to be especially important for the global macro funds. The inclusion of the carry trade factor increases the model's power to explain variation in these hedge funds' returns, measured here by adjusted R-squared, from $14.1 \%$ to $22.8 \%$. These findings suggest that hedge funds in general and global macro funds in particular are engaged in currency carry trades.

Third prediction of the model is that the amount of arbitrage capital reduces the expected returns to carry trading. The fitted polynomial trend to carry trade returns, shown in Figure 2, suggests that the returns to carry trading have indeed been decreasing over time, as the amount of arbitrage capital has grown. To show the change in the profitability of carry trades, in another way, we divide our sample period in three sub sub-periods based on the total of hedge funds' assets under management and present returns to our carry trade strategy and Sharpe ratios in each of the time periods in Figure 3.

\footnotetext{
${ }^{15}$ The seven factors used by Fung and Hsieh (2004) are three trend following factors (for bonds, currencies and commodities; Fung and Shieh, 2001), an equity market factor (S\&P500), a size spread factor (Wilshire Small Cap 1750 minus Wilshire Large Cap 750), a bond market factor (monthly change in the 10-year treasury constant maturity yield), and a credit spread factor (monthly change in the Moody's Baa yield minus 10-year treasury constant maturity yield). Data for the trend following factors is available on David Hsieh's website: http://faculty.fuqua.duke.edu/ dah7/DataLibrary/TF-FAC.xls.
} 
[Insert Figure 3 here]

During the first period, when hedge fund AUM has been below USD 100bn, the average monthly return to carry trades is $0.62 \%$ whereas it is only $0.27 \%$ during the last period when hedge fund AUM has been over USD 500bn. Also, the Sharpe ratio of carry trade strategy has approximately halved from the first period to the last providing evidence that the amount of arbitrage capital does have a negative effect on carry trade returns. ${ }^{16}$

To show the relationship between arbitrage capital and carry trade returns more formally, we regress carry trade returns on hedge fund AUM and two proxies for changes in leveraged arbitrage capital and report results in Table 5. As a proxy for the change in arbitrageurs' equity capital we use the hedge fund net asset flows. In addition to current month's flow we include both the previous month's flows in the regression arguing that in some cases the new subscriptions into funds may be invested only in the month following the subscription. ${ }^{17}$ Our measure of change in the leveraging of arbitrage capital is the change in TED spread multiplied by hedge fund AUM. An increase in the TED spread signals tightening funding conditions for arbitrageurs and hence results in a decrease in the leveraged arbitrage capital.

[Insert Table 5 here]

Since we expect the amount of arbitrage capital to have a negative impact and the changes in arbitrage capital to have a positive impact on carry trade returns, we use one-sided tests when examining the validity of these predictions. As predicted, the amount of arbitrage capital has a

\footnotetext{
${ }^{16}$ It is also likely that the transaction costs for the non-professional investors to exploit this strategy have significantly been reduced over time, which may also have contributed to this observed decline in the carry trade returns.

${ }^{17}$ We believe that endogeneity is not a problem and the current month's flow is not affected by contemporaneous return as the hedge funds typically require more than one month's notification period for redemptions and subscriptions.
} 
negative and statistically significant effect on the carry trade returns. The effect of current month's and the previous month's flows is positive, but only the joint effect of the flows is significant at a $5 \%$ level. As expected, the effect of changes in the TED spread multiplied by the hedge fund AUM is statistically very significantly negative. The observations hold both for raw returns (columns 1, 3 and 5 of Table 5) and Fama and French (1993) three factor risk adjusted returns (column 2, 4 and 6 of Table 5). Thus according to our results increases in arbitrage equity capital and higher leverage for arbitrageurs reduce the future returns to carry trades.

\section{Carry trade activity and interest rates}

According to our model, in the absence of arbitrageurs, the level of interest rate in a country is defined by the risk associated with its inflation and the per capita supply of the fixed income asset in that country. We start the empirical analysis of this prediction by testing for the stationarity of the interest rate levels in our panel of 11 currencies and 393 months. We apply the Im, Pesaran and Shin (2003) panel unit root test since it is powerful even for panels with a small number of crosssections. The test statistic is -2.6 with associated $p$-value equal to 0.005 . Hence, we can reject the hypothesis of a unit root in the data and proceed with analyzing the levels of interest rates. The finding of stationarity of interest rates is in line with the results of e.g., Wu and Zhang (1997) and Österholm (2004). Also, Aït-Sahalia (1997) shows that interest rates can behave as if they are nonstationary as long as they are within a normal range. When an interest rate is outside this range it tends to revert back towards the normal level. Hence, interest rates can exhibit local nonstationarity while being effectively stationary.

To test our basic interest rate model empirically, we regress the level of interest rates on forecasted inflation, inflation risk and the per capita money supply. The inflation forecasts are calculated as one-step-ahead forecasts from inflation model presented in equation (21). We also include country 
fixed effects in the model and report feasible generalized least squares (FGLS; see Greene, 2003) estimation results in column 1 of Table 6 .

Inflation risk and money supply are both positive and statistically significantly associated with the levels of interest rates as predicted by the theoretical model. The finding that inflation risk is a significant determinant of interest rates is in line with studies, such as Shen (1998) and Buraschi and Jiltsov (2005), that document positive and significant inflation risk premiums in nominal interest rates.

As discussed in section 2 we expect that in the presence of arbitrageurs, larger amount of arbitrage capital and better funding liquidity will lead to lower (higher) interest rates in the high (low) interest rate countries, thus decreasing the returns to carry trades. We test this prediction by including the proxy for arbitrage capital, hedge fund AUM divided by total M2 money supply, and a funding liquidity proxy, TED spread, in the interest rate level regression. As we expect that the amount of arbitrage capital and funding liquidity have opposing effects on low and high ranked interest rates, we include an indicator variable in the regression to indicate whether the country belongs to our "carry trade" short or "carry trade" long portfolio and interact the indicator variable with the arbitrage capital and funding liquidity proxies. The indicator variable, Position, equals minus one for countries that belong to the lowest third in the interest rate ranking, plus one for countries that belong to the highest third and zero for the rest of the countries. Since this variable is based on the dependent variable of the regression, we use the lagged indicator variable to avoid endogeneity issues. Results of regressing the level of interest rates on inflation forecast, inflation risk, money supply and lagged Position times the proxies for arbitrage capital and funding liquidity are presented in Table 6. Figure 4 presents the actual and the fitted levels of interest rates for each of the countries. The fitted values are based on the broadest model, presented in column 4 of Table 6 . 
[Insert Table 6 and Figure 4 here]

The hedge fund AUM has a significant effect on interest rates in the direction predicted by the theoretical model: it decreases (increases) the interest rates in high (low) interest rate countries. The level of arbitrage capital also has an overall decreasing effect on interest rates showing that higher liquidity in the market has led to lower interest rates. Also, the effect of funding liquidity is as predicted and statistically significant: higher TED spread, i.e., tighter funding liquidity, is associated with higher (lower) interest rate in the high (low) interest rate countries. Judged graphically, the fit of the model seems satisfactory.

Further, according to the theoretical model, an increase in the arbitrage capital should lead to an increase in interest rates in the low interest rate countries and a decrease in interest rates in the high interest rate countries as arbitrageurs increase their carry trade positions. Table 7 presents the results of regressing change in interest rates on changes in forecasted inflation, inflation risk and money supply as well as interaction of hedge fund flows and Position variable. We include in the regression hedge fund flows from both the current and the previous month.

\section{[Insert Table 7 here]}

Using one-sided tests, the interaction term of Position and hedge fund flows is statistically significant negative at a 5\% level, indicating that an increase in arbitrage capital leads to an increase (decrease) in the interest rates in the low (high) interest rate countries. Also, the combined effect of current and previous month's flows is significantly negative. ${ }^{18}$ Column 1 of Table 7 also serves as a

\footnotetext{
${ }^{18}$ We also estimated the interest rate change model including the interaction of Position and changes in TED spread. The results of these regressions were not statistically significant and are omitted.
} 
robustness check to the result presented in Table 6. Since the level of interest rates is highly persistent, it is useful to examine the relationship between interest rates, inflation risk and money supply also in differences. As column 1 of Table 7 shows, the observed relationships hold also in differences.

\section{Carry trade activity and exchange rates}

According to our model, carry trade activity also affects exchange rates. An increase in arbitrage capital will lead to an appreciation (depreciation) of high (low) interest rate countries as arbitrageurs increase their carry trade positions. We examine this effect by regressing the changes in spot exchange rates on forward premium and hedge fund flows and present the results in Table 8 . As we expect the hedge fund flows to have opposite effects on high and low interest rate currencies, we interact the flows with Position variable presented above. The spot exchange rate change is calculated for each currency against a basket containing all the other currencies in the sample. This way we can mitigate problems arising from using a single currency as a numeraire.

\section{[Insert Table 8 here]}

The effect of current month's hedge fund flows on spot exchange rates is very significant. During months of positive flows, high interest rate currencies appreciate and low interest rate currencies depreciate. This finding is especially timely as hedge funds are currently facing sizeable redemptions and e.g., the Japanese yen has appreciated sharply. The effect of the past month's flow is in the same direction but lacks statistical significance. The joint effect of the two flows is also statistically significant. ${ }^{19}$ These results are in line with those of Evans and Lyons (2002) who find,

\footnotetext{
${ }^{19}$ We also estimated the spot exchange rate change model including the interaction of Position and changes in TED spread. The results of these regressions were not statistically significant and are omitted.
} 
using daily data, that deal flow explains a large part of variation in exchange rates. The difference being that we are able to trace the origin of some of this deal flow to hedge funds engaged in carry trades. Note also that a similar prediction to ours that carry trades affect exchange rates is present in Plantin and Shin (2008) and Brunnermeier, Nagel and Pedersen (2008).

\section{Conclusion}

We showed that the carry trade activity, which according to our results is a major strategy for hedge funds, has grown to such high levels that it has had a price effect in the fixed income and currency markets, and it has affected the expected returns to carry trades. Our estimate of the total hedge fund assets under management (see Figure 1) reveals that such assets have in recent years been close to $6 \%$ of the M2 money supply of our sample currencies, which includes the currencies of the largest industrialized countries in the world. When assessing the magnitude of this amount, recognizing that hedge funds pursue many different strategies besides to carry trades, one must also recognize that the hedge fund investments are typically very highly leveraged, amplifying the amount of money that has been invested in carry trades. ${ }^{20}$ Given the huge amount of leveraged assets under management, it is no longer so surprising that we find that the amount and the flow of hedge fund assets under management have had such a strong price effect in the fixed income and currency markets.

According our results the carry traders transfer money from low real interest rate countries to high real interest rate countries. Although this activity is presumably good for the global allocation of resources, it has some alarming consequences that must be better understood. First, carry trading has an effect of making monetary policies of individual countries more challenging and second it

\footnotetext{
${ }^{20}$ In the past, leverage ratios of up to 12:1 have been estimated for some types of hedge funds, see McGuire, Remolona and Tsatsaronis (2005).
} 
subjects the economies to large swings in their interest and currency rates, when the amount of leveraged arbitrage capital suddenly changes. 


\section{References}

Agarwal, Vikas, Naveen D. Daniel, and Narayan Y. Naik, 2008, Role of Managerial Incentives and Discretion in Hedge Fund Performance, Journal of Finance, forthcoming.

Aït-Sahalia, Yacine, 1996, Testing Continuous-Time Models of the Spot Interest Rate, Review of Financial Studies 9, 385-426.

Albuquerque, Rui A., 2007, The Forward Premium Puzzle in a Model of Imperfect Information: Theory and Evidence, Economic Letters, forthcoming.

Alvarez, Fernando, Andrew Atkenson, and Patrick J. Kehoe, 2007, Time-Varying Risk, Interest Rates, and Exchange Rates in General Equilibrium, Federal Reserve Bank of Minneapolis Research Department Staff Report 371.

Ang, Andrew, Geert Bekaert and Min Wei (2008): The Term Structure of Real Rates and Expected Inflation, Journal of Finance 63, 797-849.

Arellano Manuel, 1987, Computing Robust Standard Errors for Within Group Estimators, Oxford bulletin of Economics and Statistics 49, 431-434.

Bacchetta, Philippe, and Eric van Wincoop, 2006, Incomplete Information Processing: A Solution to the Forward Discount Puzzle, available at SSRN: http://ssrn.com/abstract=1004808.

Backus, David K, Silverio Foresi, and Chris I. Telmer, 2001, Affine Term Structure Models and the Forward Premium Anomaly, Journal of Finance 56, 279-304.

Backus, David K., Allan W. Gregory, and Chris I. Telmer, 1993, Accounting for Forward Rates in Markets for Foreign Currency, Journal of Finance 48, 4887-1908.

Bansal, Ravi, and Magnus Dahlquist, 2000, The Forward Premium Puzzle: Different Tales from Developed and Emerging Economies, Journal of International Economics 51, 115-144. 
Bansal, Ravi, and Ivan Shaliastovich, 2006, Long-Run Risks Explanation of Forward Premium Puzzle, working paper.

Baquero, Guillermo, and, Marno Verbeek, 2005, A Portrait of Hedge Fund Investors: Flows, Performance and Smart Money, available at SSRN: http://ssrn.com/abstract=851625.

Bekaert, Geert, 1996, The Time Variation of Risk and Return in Foreign Exchange Markets: A General Equilibrium Perspective, Review of Financial Studies 9, 427-470.

Bekaert, Geert, Robert J. Hodrick, and David A. Marshall, 1997, The Implications of First-Order Risk Aversion for Asset Market Risk Premiums, Journal of Monetary Economics 40, 3-39.

Bilson, John F. O., 1981, The "Speculative Efficiency" Hypothesis, The Journal of Business 54, 435-451.

Burnside, Craig A., Martin Eichenbaum, Isaac Kleshchelski, and Sergio T. Rebelo, 2006, The Returns to Currency Speculation, NBER Working Paper No. W12489, available at SSRN: http://ssrn.com/abstract=927212.

Burnside, Craig A., Martin Eichenbaum, and Sergio T. Rebelo, 2007a, The Returns to Currency Speculation in Emerging Markets, American Economic Review 97, 333-338.

Burnside, Craig A., Martin Eichenbaum, and Sergio T. Rebelo, 2007b, Understanding the Forward Premium Puzzle: A Microstructure Approach, NBER Working Paper No. W13278, available at SSRN: http://ssrn.com/abstract=1002057.

Brunnermeier, Markus K, and Lasse Heje Pedersen, 2007, Market Liquidity and Funding Liquidity, Review of Financial Studies, forthcoming.

Brunnermeier, Markus K., Stefan Nagel, and Lasse Heje Pedersen, 2008, Carry Trades and Currency Crashes, NBER Macroeconomics Annual 2008, forthcoming. 
Buraschi, Andrea, and Alexei Jiltsov, 2005, Inflation Risk Premia and the Expectations Hypothesis, Journal of Financial Economics 75, 429-490.

Cumby, Robert E., 1988, Is it Risk? Explaining Deviations from Uncovered Interest Parity, Journal of Monetary Economics 22, 279-299.

Ding, Bill, Mila Getmansky, Bing Liang, and Russ Wermers, 2007, Hedge Fund Flows and Contagion in Financial Markets, available at SSRN: http://ssrn.com/abstract=1107413.

Ding, Bill, Mila Getmansky, Bing Liang, and Russ Wermers, 2008, Investor Flows and Share Restrictions in the Hedge Fund Industry, available at SSRN: http://ssrn.com/abstract=891732.

Einzig, Paul A., 1961, A Dynamic Theory of Forward Exchange, Macmillan.

Engel, Charles, 1996, The Forward Discount Anomaly and the Risk Premium: A Survey Of Recent Evidence, Journal of Empirical Finance 3, 123-192.

Evans, Martin D., and Richard K. Lyons, 2002, Order Flow and Exchange Rate Dynamics, Journal of Political Economy 110, 170-180.

Fama, Eugene F., 1976, Inflation Uncertainty and Expected Returns on Treasury Bills, Journal of Political Economy 84, 427-448.

Fama, Eugene F., 1984, Forward and Spot Exchange Rates, Journal of Monetary Economics 14, 319-338.

Fama, Eugene F. and André Farber, 1979, Money, bonds, and Foreign Exchange, American Economic Review 69, 639-649.

Fama, Eugene F., and Kenneth R. French, 1993, Common risk factors in the returns on stocks and bonds, Journal of Financial Economics 33, 3-56.

Farhi, Emmanuel, and Xavier Gabaix, 2008, Rare Disasters and Exchange Rates, NBER Working Paper No. W13805 available at SSRN: http://ssrn.com/abstract=1092854. 
Froot, Kenneth A. and Richard H. Thaler, 1990, Anomalies: Foreign Exchange, Journal of Economic Perspectives 4, 179-192.

Fung, William, and David A. Hsieh, 2000, Measuring the Market Impact of Hedge Funds, Journal of Empirical Finance 7, 1-36.

Fung, William, and David Hsieh, 2001, The Risk in Hedge Fund Strategies: Theory and Evidence from Trend Followers, Review of Financial Studies 14, 313-341.

Fung, William, and David Hsieh, 2004, Hedge Fund Benchmarks: A Risk Based Approach, Financial Analyst Journal 60, 65-80.

Fung, William, and David A. Hsieh, Narayan Y. Naik, and Tarun Ramadorai, 2008, Hedge funds: Performance, Risk and Capital Formation, Journal of Finance, forthcoming.

Galati, Gabriele, Alexandra Heath, and Patrick McGuire, 2007, Evidence of Carry Trade Activity, in BIS Quarterly Review, September 2007, Bank for International Settlements.

Getmansky, Mila, 2004, The Life Cycle of Hedge Funds: Fund Flows, Size and Performance, working paper.

Goetzmann, William N., Jonathan E. Ingersoll, and Stephen A. Ross, 2003, High-Water Marks and Hedge Fund Management Contracts, Journal of Finance 58, 1685-1718.

Gourinchas, Pierre-Oliver, and Aaron Tornell, 2004, Exchange Rate Puzzles and Distorted Beliefs, Journal of International Economics 64, 303-333.

Grauer, Frederick L. A., Robert H. Litzenberger, and Richard E. Stehle, 1976, Sharing Rules and Equilibrium in an International Capital Market under Uncertainty, Journal of Financial Economics 3, 233-256.

Greene, William H., 2003, Econometric Analysis, $5^{\text {th }}$ edition, Prentice Hall. 
Grier, Kevin B., and Mark J. Perry, 1998, On Inflation and Inflation Uncertainty in the G7 Countries, Journal of International Money and Finance 17, 671-689.

Gromb, Denis, and Dimitri Vayanos, 2002, Equilibrium and Welfare in Markets with Financially Constrained Arbitrageurs, Journal of Financial Economics, 66, 361-407.

Grossman, Sanford J., 1995, Dynamic Asset Allocation and Informational Efficiency of Markets, The Journal of Finance 50, 773-789.

Han, Bing, David A. Hirshleifer, and Tracy Yue Wang, 2007, Investor Overconfidence and the Forward Discount Puzzle, available at SSRN: http://ssrn.com/abstract=841038.

Hollifield, Burton, and Raman Uppal, 1997, An Examination of Uncovered Interest Rate Parity in Segmented International Commodity Markets, Journal of Finance 52, 2145-2170.

Hwang, Y., 2001, Relationship Between Inflation Rate and Inflation Uncertainty, Economics Letters 73, 179-186.

Im, Kyung So, M. Hashem Pesaran, Yongcheol Shin, 2003, Testing for Unit Roots in Heterogeneous Panels, Journal of Econometrics 115, 53-74.

International Monetary Fund, 2007, Review of Exchange Arrangements, Restrictions, and Controls, available at http://www.imf.org/External/NP/pp/2007/eng/112707.pdf.

Keynes, John Maynard, 1923, A Tract on Monetary Reform, Macmillan \& Co.

Korajczyk, Robert A., 1985, The Pricing of Forward Contracts for Foreign Exchange, Journal of Political Economy 93, 346-368.

Kouri, Pentti J. K., 1977, International Investment and Interest Rate Linkages under Flexible Exchange Rates, in Robert Z. Aliber (ed.) The Political Economy of Monetary Reform, Macmillan. 
Lustig, Hanno, Nick Roussanov, and Adrien Verdelhan, 2008, Common Risk Factors in the Returns on Currencies, working paper.

Lustig, Hanno, and Adrien Verdelhan, 2007, The Cross-Section of Foreign Currency Risk Premia and U.S. Consumption Growth Risk, American Economic Review, 97, 89-117.

Lyons, Richard K., 2001, The Microstructure Approach to Exchange Rates, MIT Press.

Lyytinen, Jussi-Pekka, 2007, Currency Carry Trades - Betting against the Uncovered Interest Parity, Master's Thesis supervised by Matti Suominen at the Helsinki School of Economics.

Mark, Nelson C., and Yangru Wu, 1998, Rethinking Deviations from Uncovered Interest Parity: the Role of Covariance Risk and Noise, The Economic Journal 108, 1686-1706.

McGuire, Patrick, Eli Remolona and Kostas Tsatsaronis, 2005, Time-Varying Exposures and Leverage in Hedge Funds, in BIS Quarterly Review March 2005, Bank for International Settlements.

McGuire, Patrick, and Christian Upper, 2007, Detecting FX Carry Trades, in BIS Quarterly Review, March 2007, Bank for International Settlements.

Mitchell, Brian R., 1992, International Historical Statistics: Europe 1950-1988, Stockton Press.

Newey, Whitney K., and Kenneth D. West, 1987, A Simple, Positive Semi-Definite, Heteroskedasticity and Autocorrelation Consistent Covariance Matrix. Econometrica 55, 703708.

Österholm, Pär, 2004, Killing Four Unit Root Birds in the US Economy with Three Panel Unit Root Test Stones, Applied Economics Letters 11, 213-216.

Plantin, Guillaume, and Hyun Song Shin, 2008, Carry Trades and Speculative Dynamics, working paper. 
Roll, Richard, and Shu Yan, 2000, An Explanation of the Forward Premium 'Puzzle', European Financial Management 6, 121-148.

Shen, Pu, 1998, How Important Is the Inflation Risk Premium, Federal Reserve Bank of Kansas City, Economic Review, Fourth Quarter, 36-47

Vayanos, Dimitri, and Jean-Luc Vila, 2007, A Preferred-Habitat Model of the Term Structure of Interest Rates, available at SSRN: http://ssrn.com/abstract=971439.

Verdelhan, Adrien, 2007, A Habit-Based Explanation of the Exchange Rate Risk Premium, working paper.

Wagner, Christian, 2008, Risk-Premia, Carry-Trade Dynamics, and Speculative Efficiency of Currency Markets, available at SSRN: http://ssrn.com/abstract=921339.

Wang, Ashley, and Lu Zheng, 2008, Aggregate Hedge Fund Flows and Asset Returns, available at SSRN: http://ssrn.com/abstract=1081475.

Wu, Yangru, and Hua Zhang, 1997, Do Interest Rates Follow Unit-Root Processes? Evidence from Cross-Maturity Treasury Bill Yields, Review of Quantitative Finance and Accounting 8, 69-81. 


\section{Appendix:}

Proof of Equation 15:

$\frac{P_{H}}{P_{L}}=\frac{1-\left(M_{H}-K \lambda_{H}^{a}\right) a \sigma_{H}^{2}}{1-\left(M_{L}-K \lambda_{L}^{a}\right) a \sigma_{L}^{2}}=\frac{1-\left[M_{H}-K\left[\frac{1-P_{H} / P_{L}}{a \sigma_{H}^{2}+\left(P_{H} / P_{L}\right)^{2} a \sigma_{L}^{2}}\right]\right] a \sigma_{H}^{2}}{1-\left[M_{L}+K \frac{P_{H}}{P_{L}}\left[\frac{1-P_{H} / P_{L}}{a \sigma_{H}^{2}+\left(P_{H} / P_{L}\right)^{2} a \sigma_{L}^{2}}\right]\right] a \sigma_{L}^{2}}$

$\Leftrightarrow$

$\frac{P_{H}}{P_{L}}\left(1-\left[M_{L}+K \frac{P_{H}}{P_{L}}\left[\frac{1-P_{H} / P_{L}}{a \sigma_{H}^{2}+\left(P_{H} / P_{L}\right)^{2} a \sigma_{L}^{2}}\right]\right] a \sigma_{L}^{2}\right)=1-\left[M_{H}-K\left[\frac{1-P_{H} / P_{L}}{a \sigma_{H}^{2}+\left(P_{H} / P_{L}\right)^{2} a \sigma_{L}^{2}}\right]\right] a \sigma_{H}^{2}$

$\Leftrightarrow$

$\frac{P_{H}}{P_{L}}\left(1-M_{L} a \sigma_{L}^{2}\right)=1-M_{H} a \sigma_{H}^{2}+K\left[\frac{\left(1-P_{H} / P_{L}\right) a \sigma_{H}^{2}}{a \sigma_{H}^{2}+\left(P_{H} / P_{L}\right)^{2} a \sigma_{L}^{2}}+\left(P_{H} / P_{L}\right)^{2}\left[\frac{\left(1-P_{H} / P_{L}\right) a \sigma_{L}^{2}}{a \sigma_{H}^{2}+\left(P_{H} / P_{L}\right)^{2} a \sigma_{L}^{2}}\right]\right]$

$\Leftrightarrow$

$\frac{P_{H}}{P_{L}}\left(1-M_{L} a \sigma_{L}^{2}\right)=\left(1-M_{H} a \sigma_{H}^{2}\right)+K\left(1-P_{H} / P_{L}\right)$

$\Leftrightarrow$

$\frac{P_{H}}{P_{L}}=\frac{\left(1+K-M_{H} a \sigma_{H}^{2}\right)}{\left(1+K-M_{L} a \sigma_{L}^{2}\right)}$ 
Table 1. Descriptive statistics of carry trade returns.

This table presents the basic descriptive statistics of monthly gross returns to carry trade strategy. Short refers to portfolio of short positions in low interest rate currencies, Long refers to portfolio of long positions in high interest rate currencies, and Short+Long refers to portfolio of short positions in low interest rate currencies and long positions in high interest rate currencies. $t$-values are given in parenthesis for selected statistics.

\begin{tabular}{lrrr}
\hline \hline & Short+Long & Short & Long \\
\hline Mean & $0.49 \%$ & $0.27 \%$ & $0.23 \%$ \\
& $(4.828)$ & $(2.053)$ & $(2.475)$ \\
Standard deviation & $2.03 \%$ & $2.60 \%$ & $1.80 \%$ \\
Sharpe ratio & 0.244 & 0.103 & 0.125 \\
Skewness & -0.629 & -0.635 & 0.898 \\
\hline \hline
\end{tabular}

Table 2. Carry trade positions.

This table presents the number of total months a position is in individual currencies over the sample period. Figures in parenthesis show the number of months divided by the length of the sample for the particular currency. Short refers to portfolio of short positions in low interest rate currencies, Long refers to portfolio of long positions in high interest rate currencies, and Short+Long refers to portfolio of short positions in low interest rate currencies and long positions in high interest rate currencies.

\begin{tabular}{l|rr|rr|rr}
\hline \hline & \multicolumn{2}{|c|}{ Short+Long } & \multicolumn{2}{c|}{ Short } & \multicolumn{2}{c}{ Long } \\
\hline BEF & 73 & $(26.4 \%)$ & 8 & $(2.9 \%)$ & 65 & $(23.6 \%)$ \\
CAD & 165 & $(43.0 \%)$ & 28 & $(7.3 \%)$ & 137 & $(35.7 \%)$ \\
CHF & 348 & $(90.6 \%)$ & 348 & $(90.6 \%)$ & 0 & $(0.0 \%)$ \\
DEM & 175 & $(63.4 \%)$ & 168 & $(60.9 \%)$ & 7 & $(2.5 \%)$ \\
EUR & 25 & $(22.9 \%)$ & 1 & $(0.9 \%)$ & 24 & $(22.0 \%)$ \\
FRF & 135 & $(48.9 \%)$ & 4 & $(1.4 \%)$ & 131 & $(47.5 \%)$ \\
GBP & 293 & $(76.3 \%)$ & 1 & $(0.3 \%)$ & 292 & $(76.0 \%)$ \\
ITL & 268 & $(97.1 \%)$ & 0 & $(0.0 \%)$ & 268 & $(97.1 \%)$ \\
JPY & 319 & $(89.9 \%)$ & 319 & $(89.9 \%)$ & 0 & $(0.0 \%)$ \\
NLG & 108 & $(39.1 \%)$ & 99 & $(35.9 \%)$ & 9 & $(3.3 \%)$ \\
USD & 177 & $(46.1 \%)$ & 67 & $(17.4 \%)$ & 110 & $(28.6 \%)$ \\
\hline \hline
\end{tabular}


Table 3. Correlations with other asset classes.

This table presents the correlation between returns to carry trade and other asset classes. Data for S\&P 500 and Lehman US Aggregate are from January 1976 through September 2008. Data for Credit Suisse/Tremont Hedge Fund indices are from December 1993 through August 2008, except for Multi-Strategy for which data begin in April 1994. $p$-values are given for the test that the correlation is equal to zero.

\begin{tabular}{lrr}
\hline \hline & Correlation & $p$-value \\
\hline S\&P 500 & 0.079 & 0.118 \\
Lehman US Aggregate & -0.090 & 0.076 \\
Hedge funds & 0.258 & 0.001 \\
Convertible Arbitrage & 0.266 & 0.000 \\
Dedicated Short Bias & -0.024 & 0.754 \\
Emerging Markets & 0.189 & 0.012 \\
Equity Market Neutral & -0.083 & 0.271 \\
Event Driven & 0.175 & 0.021 \\
Fixed Income Arbitrage & 0.332 & 0.000 \\
Global Macro & 0.252 & 0.001 \\
Long/Short Equity & 0.096 & 0.203 \\
Managed Futures & -0.027 & 0.720 \\
Multi-Strategy & 0.111 & 0.144 \\
\hline \hline
\end{tabular}

Table 4. Carry trade factor in hedge fund index returns.

This table presents the results of regressing returns of three hedge fund indices on the seven risk factors introduced by Fung and Hsieh (2001) and currency carry trade returns. Data is monthly from January 1994 through March 2008. Data for the Fung and Hsieh factors is available at http://faculty.fuqua.duke.edu/ dah7/HFRFData.htm. Heteroskedasticity and autocorrelation consistent $t$-values (Newey and West, 1987) are reported in parenthesis.

\begin{tabular}{l|rr|rr|rr}
\hline \hline & \multicolumn{2}{|c|}{ Hedge fund } & \multicolumn{2}{|c|}{ Global macro } & Fixed income arbitrage \\
\hline Constant & 0.0063 & 0.0049 & 0.0097 & 0.0075 & 0.0049 & 0.0042 \\
& $(5.51)$ & $(4.56)$ & $(5.07)$ & $(3.52)$ & $(5.29)$ & $(4.23)$ \\
Bond trend following factor & -0.0254 & -0.0243 & -0.0283 & -0.0263 & -0.0116 & -0.0111 \\
& $(-2.12)$ & $(-1.99)$ & $(-1.68)$ & $(-1.54)$ & $(-1.78)$ & $(-1.64)$ \\
Currency trend following factor & 0.0123 & 0.0189 & 0.0191 & 0.0301 & -0.0069 & -0.0038 \\
& $(1.68)$ & $(2.61)$ & $(1.32)$ & $(2.18)$ & $(-1.07)$ & $(-0.76)$ \\
Commodity trend following factor & 0.0240 & 0.0249 & 0.0279 & 0.0295 & 0.0122 & 0.0126 \\
& $(2.03)$ & $(2.33)$ & $(1.34)$ & $(1.53)$ & $(1.91)$ & $(2.10)$ \\
Equity market factor & 0.2578 & 0.2687 & 0.1500 & 0.1682 & -0.0200 & -0.0148 \\
& $(5.62)$ & $(7.00)$ & $(1.72)$ & $(2.27)$ & $(-0.63)$ & $(-0.55)$ \\
Size spread factor & 0.1815 & 0.1742 & 0.0647 & 0.0524 & 0.0034 & -0.0001 \\
& $(3.36)$ & $(3.43)$ & $(0.95)$ & $(0.86)$ & $(0.22)$ & $(-0.01)$ \\
Bond market factor & -0.0241 & -0.0225 & -0.0412 & -0.0384 & -0.0154 & -0.0146 \\
& $(-3.72)$ & $(-3.56)$ & $(-3.59)$ & $(-3.62)$ & $(-2.61)$ & $(-2.80)$ \\
Credit spread factor & -0.0310 & -0.0197 & -0.0457 & -0.0267 & -0.0397 & -0.0342 \\
& $(-2.04)$ & $(-1.58)$ & $(-1.75)$ & $(-1.23)$ & $(-3.07)$ & $(-3.44)$ \\
Currency carry trade return & & 0.2820 & & 0.4733 & $(2.63)$ & 0.1355 \\
& & $(3.30)$ & & 0.228 & 0.154 & 0.199 \\
\hline Adjusted R-squared & 0.425 & 0.485 & 0.141 & & $(2.03)$ \\
\hline \hline
\end{tabular}




\section{Table 5. Carry trade returns and arbitrage capital.}

This table gives the results of regressing monthly returns to carry trade strategy on proxies of the amount of and changes in arbitrage capital. The proxy for arbitrage capital (AUM) is the total hedge fund assets under management scaled by the total M2 money supply of the sample countries. Proxies for changes in arbitrage capital are hedge fund flows, scaled by the total M2 money supply, and changes in TED spread (spread between 3 month Treasury bill and 3 month Eurodollar rates) multiplied by the arbitrage capital proxy. Mkt-rf, HML and SMB are the Fama and French (1993) risk factors. Heteroskedasticity and autocorrelation consistent $t$-values (Newey and West, 1987) are reported in parenthesis.

\begin{tabular}{|c|c|c|c|c|c|c|}
\hline $\begin{array}{l}\text { Dependent: carry trade } \\
\text { return }\end{array}$ & (1) & (2) & (3) & (4) & $(5)$ & (6) \\
\hline Constant & $\begin{array}{r}0.0065 \\
(4.36)\end{array}$ & $\begin{array}{r}0.0061 \\
(4.06)\end{array}$ & $\begin{array}{r}0.0067 \\
(4.52)\end{array}$ & $\begin{array}{r}0.0061 \\
(4.16)\end{array}$ & $\begin{array}{r}0.0064 \\
(4.23)\end{array}$ & $\begin{array}{r}0.0059 \\
(3.91)\end{array}$ \\
\hline AUM & $\begin{array}{r}-0.1395 \\
(-2.21)\end{array}$ & $\begin{array}{r}-0.1332 \\
(-2.14)\end{array}$ & $\begin{array}{r}-0.0962 \\
(-1.70)\end{array}$ & $\begin{array}{r}-0.0917 \\
(-1.68)\end{array}$ & $\begin{array}{r}-0.1270 \\
(-2.07)\end{array}$ & $\begin{array}{r}-0.1207 \\
(-2.00)\end{array}$ \\
\hline Hedge fund flow (t) & $\begin{array}{r}1.6820 \\
(1.20)\end{array}$ & $\begin{array}{r}1.7781 \\
(1.31)\end{array}$ & & & $\begin{array}{r}1.9891 \\
(1.44)\end{array}$ & $\begin{array}{r}2.0569 \\
(1.53)\end{array}$ \\
\hline Hedge fund flow (t-1) & $\begin{array}{r}2.4789 \\
(1.69)\end{array}$ & $\begin{array}{r}2.2512 \\
(1.54)\end{array}$ & & & $\begin{array}{r}2.1805 \\
(1.58)\end{array}$ & $\begin{array}{r}1.9014 \\
(1.36)\end{array}$ \\
\hline$\Delta \mathrm{TED} \times \mathrm{AUM}$ & & & $\begin{array}{r}-0.2424 \\
(-2.90)\end{array}$ & $\begin{array}{r}-0.2613 \\
(-3.10)\end{array}$ & $\begin{array}{r}-0.2407 \\
(-3.03)\end{array}$ & $\begin{array}{r}-0.2575 \\
(-3.25)\end{array}$ \\
\hline$\Delta \mathrm{TED}$ & & & $\begin{array}{r}0.0034 \\
(1.10)\end{array}$ & $\begin{array}{r}0.0058 \\
(1.69)\end{array}$ & $\begin{array}{r}0.0033 \\
(1.04)\end{array}$ & $\begin{array}{r}0.0055 \\
\quad(1.57)\end{array}$ \\
\hline Mkt-rf & & $\begin{array}{r}0.0004 \\
(1.66)\end{array}$ & & $\begin{array}{r}0.0005 \\
(2.06)\end{array}$ & & $\begin{array}{r}0.0005 \\
(1.91)\end{array}$ \\
\hline HML & & $\begin{array}{r}0.0003 \\
(0.63)\end{array}$ & & $\begin{array}{r}0.0005 \\
(1.30)\end{array}$ & & $\begin{array}{r}0.0004 \\
(0.87)\end{array}$ \\
\hline SMB & & $\begin{array}{r}0.0001 \\
(0.36) \\
\end{array}$ & & $\begin{array}{r}0.0003 \\
(0.72) \\
\end{array}$ & & $\begin{array}{r}0.0002 \\
(0.47) \\
\end{array}$ \\
\hline R-squared & 0.017 & 0.024 & 0.019 & 0.029 & 0.027 & 0.036 \\
\hline
\end{tabular}


Table 6. Interest rates, inflation risk, money supply and arbitrage capital.

This table gives the FGLS results of regressing monthly level of interest rates on forecasted inflation, logarithm of inflation risk (fitted value from a GARCH(1,1) model on monthly inflation), logarithm of money supply (M2 divided by stock market capitalization), proxy for arbitrage capital (AUM = total hedge fund assets under management scaled by the total M2 money supply of the sample countries) interacted with position variable that is equal to one if the country is in the carry trade long portfolio during the month, negative one if the country is in the carry trade short portfolio during the month and zero otherwise, and proxy for funding liquidity (TED spread, spread between 3 month Treasury bill and 3 month Eurodollar rates) interacted with the same indicator variable, position. Country fixed effects are included in the estimation. Heteroskedasticity and autocorrelation consistent $t$-values (Arellano, 1987) are reported in parenthesis.

\begin{tabular}{lrrrr}
\hline \hline Dependent: interest rate & $(1)$ & $(2)$ & $(3)$ & $(4)$ \\
\hline Inflation forecast & 0.3117 & 0.2718 & 0.2117 & 0.1874 \\
& $(3.63)$ & $(3.53)$ & $(4.23)$ & $(3.68)$ \\
Log(inflation risk) & 0.0010 & 0.0009 & 0.0007 & 0.0007 \\
& $(1.97)$ & $(3.98)$ & $(1.79)$ & $(4.09)$ \\
Log(money supply) & 0.0018 & 0.0009 & 0.0012 & 0.0003 \\
& $(3.70)$ & $(2.18)$ & $(3.32)$ & $(0.92)$ \\
Position $\times$ AUM & & -0.0285 & & -0.0240 \\
& & $(-2.25)$ & & $(-2.58)$ \\
Position $\times$ TED & & & 0.0007 & 0.0006 \\
& & & $(3.19)$ & $(3.43)$ \\
Position & & 0.0019 & 0.0008 & 0.0013 \\
& & $(7.86)$ & $(3.68)$ & $(6.27)$ \\
AUM & & -0.0801 & & -0.0762 \\
TED & & $(-9.06)$ & & $(-10.21)$ \\
& & & 0.0014 & 0.0014 \\
\hline \hline
\end{tabular}


Table 7. Changes in interest rates, inflation risk, money supply and arbitrage capital.

This table gives the FGLS results of regressing changes in interest rates on changes in forecasted inflation, logarithm of inflation risk (fitted value from a GARCH( 1,1$)$ model on monthly inflation), logarithm of money supply (M2 divided by stock market capitalization), and hedge fund flows (scaled by the total M2 money supply of the sample countries) interacted with position variable that is equal to one if the country is in the carry trade long portfolio during the month, negative one if the country is in the carry trade short portfolio during the month and zero otherwise. Country fixed effects are included in the estimation. Heteroskedasticity and autocorrelation consistent $t$-values (Arellano, 1987) are reported in parenthesis.

\begin{tabular}{lrr}
\hline \hline Dependent: interest rate change & $(1)$ & $(2)$ \\
\hline$\Delta$ Inflation forecast & -0.0090 & -0.0423 \\
& $(-0.79)$ & $(-2.06)$ \\
$\Delta \log ($ inflation risk) & 0.0004 & 0.0003 \\
& $(2.04)$ & $(1.24)$ \\
$\Delta \log ($ money supply) & 0.0051 & 0.0065 \\
& $(3.96)$ & $(4.21)$ \\
Position $\times$ Hedge fund flow $(\mathrm{t})$ & & -0.2595 \\
& & $(-1.95)$ \\
Position $\times$ Hedge fund flow (t-1) & & -0.4508 \\
& & $(-2.32)$ \\
Position & & 0.0003 \\
& & $(3.77)$ \\
Hedge fund flow $(\mathrm{t})$ & & 0.0951 \\
& & $(1.08)$ \\
Hedge fund flow $(\mathrm{t}-1)$ & & 0.0687 \\
& & $(0.54)$ \\
\hline \hline
\end{tabular}

Table 8. Changes in exchange rates and arbitrage capital.

This table gives the FGLS results of regressing monthly changes in spot exchange rates on forward premium and hedge fund flows (scaled by the total M2 money supply of the sample countries) interacted with position variable that is equal to one if the country is in the carry trade long portfolio during the month, negative one if the country is in the carry trade short portfolio during the month and zero otherwise. The spot exchange rate change is calculated for each currency as a change in the value of the currency against a basket containing all the other currencies in the sample. Hence, a positive (negative) change indicates appreciation (depreciation) of the currency. Country fixed effects are included in the estimation. Heteroskedasticity and autocorrelation consistent $t$-values (Arellano, 1987) are reported in parenthesis.

\begin{tabular}{lr}
\hline \hline Dependent: exchange rate change & \\
\hline Forward premium & 0.4629 \\
& $(1.46)$ \\
Position $\times$ Hedge fund flow $(\mathrm{t})$ & 1.5333 \\
& $(7.35)$ \\
Position $\times$ Hedge fund flow $(\mathrm{t}-1)$ & 1.3291 \\
& $(1.08)$ \\
Position & 0.0021 \\
& $(1.85)$ \\
Hedge fund flow $(\mathrm{t})$ & -0.1215 \\
& $(-0.25)$ \\
Hedge fund flow $(\mathrm{t}-1)$ & -0.0072 \\
& $(-0.01)$ \\
\hline \hline
\end{tabular}


Figure 1. Historical development of hedge fund AUM to total M2.

This figure shows the historical development of our arbitrage capital proxy, i.e. the hedge fund industry's total AUM divided by the total M2 money supply of the sample countries.

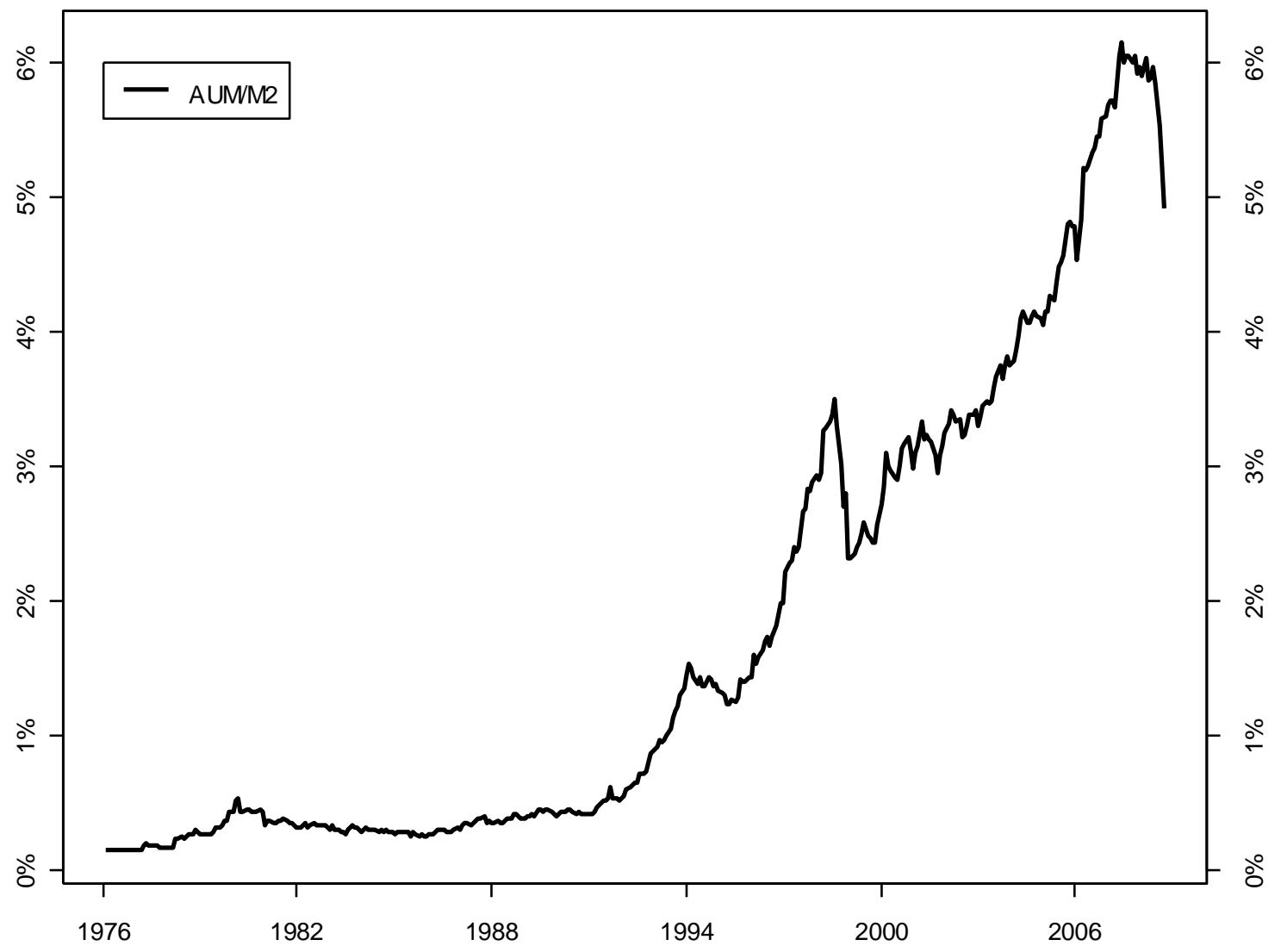


Figure 2. Cumulative performance of carry trade strategy.

This figure shows the cumulative return, in pounds, to a constant 100 pound size investment in carry trade strategy from 1976 through 2007 . The bold line present the cumulative carry trade return and the dotted line presents a second order polynomial fitted to the cumulative return data.

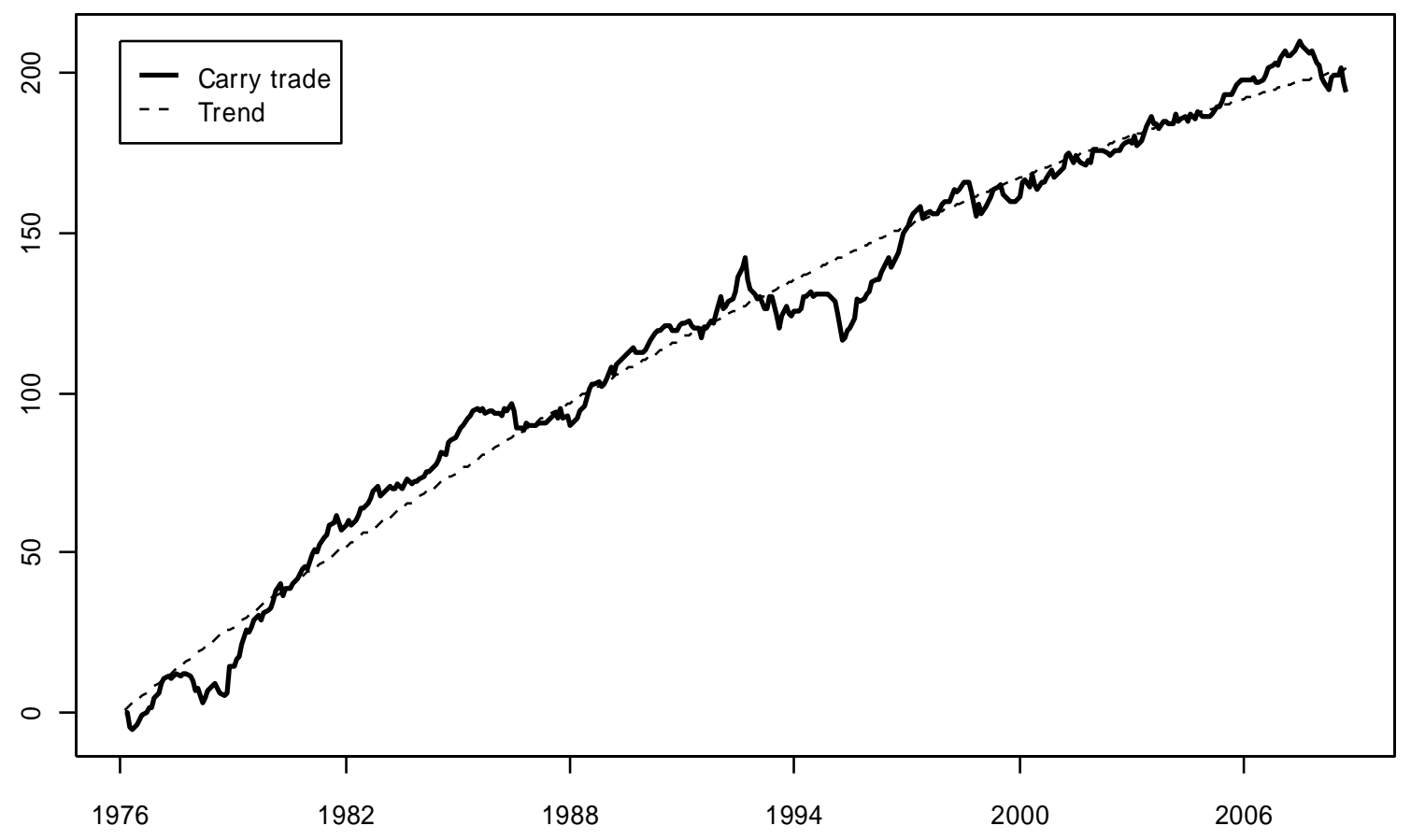

Figure 3. Carry trade performance and hedge fund assets.

This figure shows the monthly mean return (black bar, left scale) and Sharpe ratio (gray bar, right scale) when the total hedge fund assets under management has been below USD 100bn (1976-1992), between USD 100bn and 500bn (1993 2000) and above USD 500bn (2001-2008).

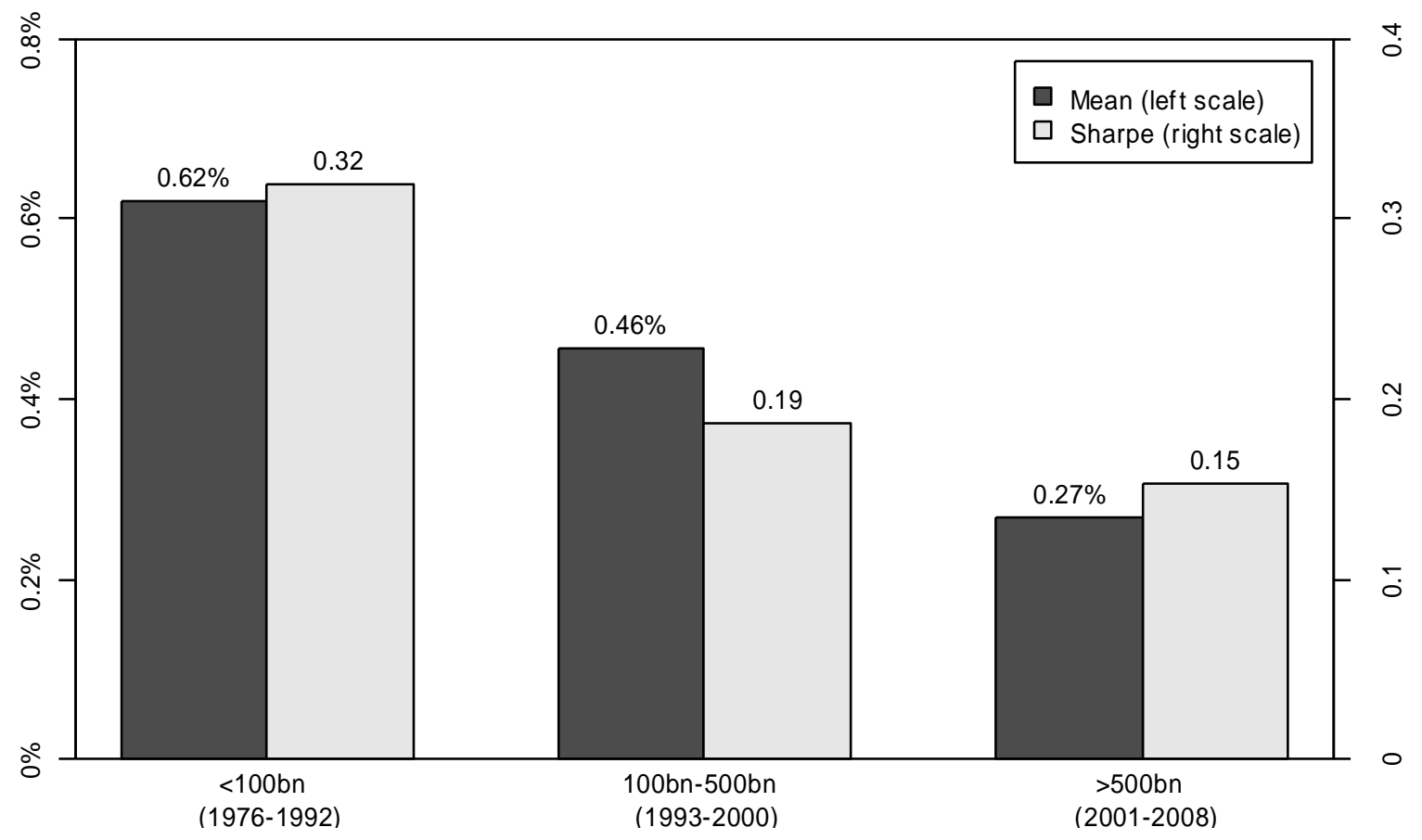


Figure 4. Interest rate estimates.

The graphs present actual (black line) and fitted (gray line) interest rates for each country. Fitted values of interest rates are based on the model presented in column 4 of Table 6.
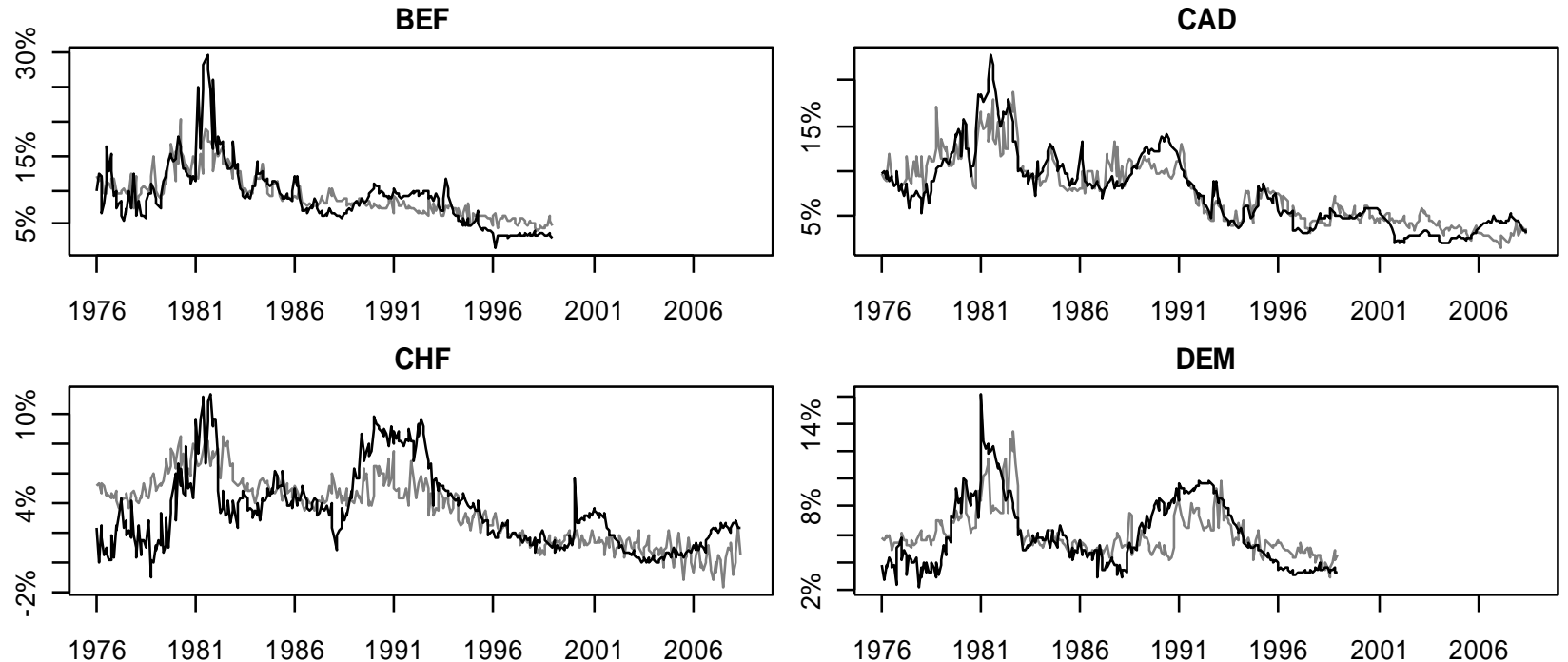

EUR
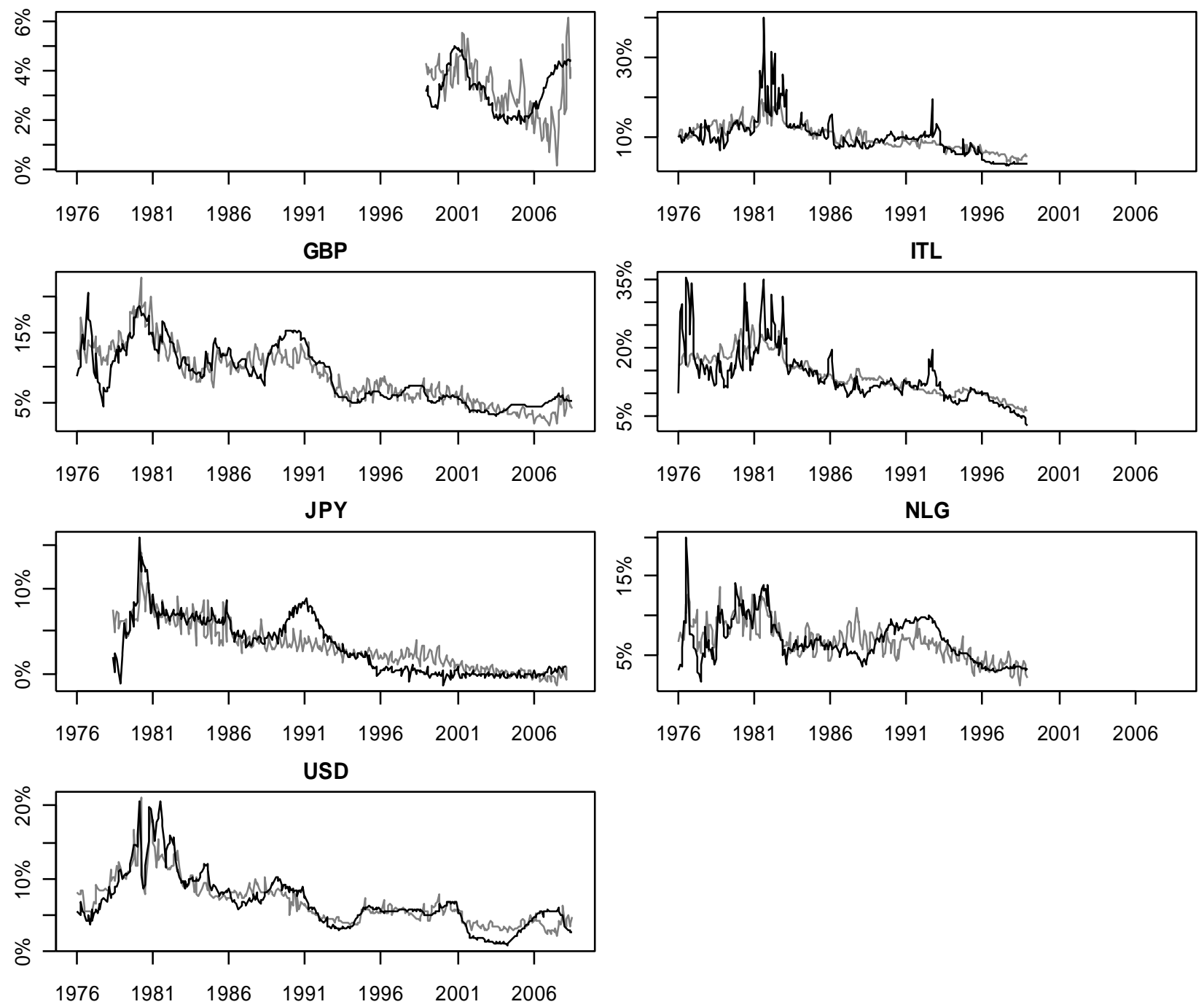